\title{
Antioxidant and Anti-Inflammatory Potential of Polyphenols Contained in Mediterranean Diet in Obesity: Molecular Mechanisms
}

\author{
Abdelhafid Nani ${ }^{1,2} *$, Babar Murtaza ${ }^{2}$, Amira Sayed Khan ${ }^{2}$, Naim Akhtar Khan ${ }^{2}$ and Aziz Hichami ${ }^{2, *}$ (D) \\ 1 Laboratory of Saharan Natural Resources, African University Ahmed Draia, Adrar 01000, Algeria \\ 2 Physiologie de la Nutrition \& Toxicologie, U1231 INSERM/Université de Bourgogne-Franche \\ Comté (UBFC)/Agro-Sup, 21000 Dijon, France; babarmurtaza87@gmail.com (B.M.); \\ Amira.Khan@u-bourgogne.fr (A.S.K.); naim.khan@u-bourgogne.fr (N.A.K.) \\ * Correspondence: nani.abdelhafid@univ-adrar.dz (A.N.); aziz.hichami@u-bourgogne.fr (A.H.)
}

\section{check for} updates

Citation: Nani, A.; Murtaza, B.; Sayed Khan, A.; Khan, N.A.; Hichami, A. Antioxidant and Anti-Inflammatory Potential of Polyphenols Contained in Mediterranean Diet in Obesity: Molecular Mechanisms. Molecules 2021, 26, 985. https://doi.org/ $10.3390 /$ molecules 26040985

Academic Editor:

Celestino Santos-Buelga

Received: 20 December 2020

Accepted: 9 February 2021

Published: 12 February 2021

Publisher's Note: MDPI stays neutral with regard to jurisdictional claims in published maps and institutional affiliations.

Copyright: (c) 2021 by the authors. Licensee MDPI, Basel, Switzerland. This article is an open access article distributed under the terms and conditions of the Creative Commons Attribution (CC BY) license (https:/ / creativecommons.org/licenses/by/ $4.0 /)$.

\begin{abstract}
Nutrition transition can be defined as shifts in food habits, and it is characterized by high-fat (chiefly saturated animal fat), hypercaloric and salty food consumption at the expense of dietary fibers, minerals and vitamins. Western dietary patterns serve as a model for studying the impact of nutrition transition on civilization diseases, such as obesity, which is commonly associated with oxidative stress and inflammation. In fact, reactive oxygen species (ROS) overproduction can be associated with nuclear factor- $\kappa \mathrm{B}(\mathrm{NF}-\mathrm{\kappa} \mathrm{B})$-mediated inflammation in obesity. NF- $\mathrm{k}$ B regulates gene expression of several oxidant-responsive adipokines including tumor necrosis factor- $\alpha$ (TNF- $\alpha$ ). Moreover, AMP-activated protein kinase (AMPK), which plays a pivotal role in energy homeostasis and in modulation of metabolic inflammation, can be downregulated by IкB kinase (IKK)-dependent TNF- $\alpha$ activation. On the other hand, adherence to a Mediterranean-style diet is highly encouraged because of its healthy dietary pattern, which includes antioxidant nutraceuticals such as polyphenols. Indeed, hydroxycinnamic derivatives, quercetin, resveratrol, oleuropein and hydroxytyrosol, which are well known for their antioxidant and anti-inflammatory activities, exert anti-obesity proprieties. In this review, we highlight the impact of the most common polyphenols from Mediterranean foods on molecular mechanisms that mediate obesity-related oxidative stress and inflammation. Hence, we discuss the effects of these polyphenols on a number of signaling pathways. We note that Mediterranean diet (MedDiet) dietary polyphenols can de-regulate nicotinamide adenine dinucleotide phosphate (NADPH) oxidase (NOX) and NF- $\mathrm{kB}$-mediated oxidative stress, and metabolic inflammation. MedDiet polyphenols are also effective in upregulating downstream effectors of several proteins, chiefly AMPK.
\end{abstract}

Keywords: MedDiet; polyphenols; obesity; oxidative stress; inflammation; AMPK; NF-кB

\section{Introduction}

Since being noticed in the 1960s for its beneficial role in coronary heart disease, consistent evidence shows that a Mediterranean diet (MedDiet) can prevent diet-related chronic diseases, such as metabolic syndrome including obesity [1]. MedDiet is a generic term that refers to the traditional eating habits in countries bordering the Mediterranean Sea, such as Greece and Italy. Although eating styles may vary among countries, greater intake of extra virgin olive oil, whole cereal grains, fruits, vegetables, legumes and nuts; low to moderate intake of dairy products, red meat and red wine; and low intake of sweets and eggs are the common components of MedDiet [2]. Various studies have demonstrated that Mediterranean-style diets provide high levels of phytochemicals, including dietary polyphenols [3-6], which have been reported to exert beneficial biological effects, including antioxidant, anti-inflammatory, immunomodulatory, antitumoral, antidiabetic and antiobesity activities [4,7-14]. 
Overnutrition and inadequate/unbalanced nutrient consumption are major risk factors for obesity $[15,16]$. Obesity can be defined as an abnormal or excessive fat accumulation that presents a risk to health. Obesity is accompanied by low-grade inflammation characterized by increased pro-inflammatory cytokines and adipokines, and release of interleukin- $1 \beta$ (IL-1 $\beta$ ), interleukin-6 (IL-6), TNF- $\alpha$, and leptin by white adipose tissue (WAT) cells or inflammatory cells infiltrating obese adipose tissue $[17,18]$. Many efforts have already been undertaken to develop novel drugs targeting proteins involved in the pathogenesis of obesity, including enzymes and transcription factors with little to no side effects on cardiovascular function [19]. Hence, there has been an increasing interest in antioxidant nutraceuticals, including dietary polyphenols, due to their anti-obesity potential [7]. Dietary polyphenol-based therapeutic approaches have been gaining interest as treatment options against chronic inflammatory diseases because of their effectiveness and nontoxic nature $[20,21]$. A number of review articles have provided a helpful context in this regard to enhance our understanding of the role of polyphenols in obesity [7,22-27]. For example, Ramadori et al. have shown that resveratrol administration to diet-induced obese mice improved hyperinsulinemia through the modulation of hypothalamic nuclear factor- $\mathrm{kB}$ inflammatory signaling [28]. Likewise, resveratrol, quercetin, and Epigallocatechin-3O-gallate (EGCG) have been reported to modulate AMPK signaling pathways, a major metabolic-sensing protein which plays a pivotal role in preventing metabolic disorders through different mechanisms. Thus, AMPK has been suggested as a potential target for obesity prevention by naturally occurring polyphenols [22,23,25]. Yet, Mohamed et al. argue the exploration of synergistic activity of polyphenols as an alternative strategy for treatment of obesity [24]. The anti-obesity effects of Mediterranean dietary polyphenols have been reviewed by Castro-Barquero et al. [26], but comprehensive reports on the effect of MedDiet on inflammation and oxidative stress associated with obesity are still lacking. In the current review, we will highlight the effect of polyphenols commonly found in a Mediterranean-style diet on oxidative stress and inflammation associated with obesity.

\section{Nutrition Transition, Oxidative Stress and Inflammation}

During the past few decades, both developed and developing countries have witnessed significant shifts in food habits. In fact, there is frequent consumption of fast food and processed, high-calorie food at the expense of ancestral traditional diets [29,30]. These shifts in food habits are known as nutrition transition characterized by high-fat (chiefly saturated animal fat), hypercaloric and salty food consumption at the expense of dietary fibers, minerals, and vitamins. Nutrition transition predisposes people to numerous noncommunicable diseases, collectively known as chronic diseases [30]. High-fat, cafeteria and Western dietary patterns have served as models for studying the impact of nutrition transition on non-communicable diseases, including obesity [31]. These diets constitute a risk factor for oxidative stress and inflammation associated with metabolic diseases [29,32-37]. It has been shown that a Western diet causes derangements of fatty acid metabolism and impairs the heart energy metabolism, mainly through oxidative phosphorylation uncoupling and free fatty acid oxidation maladaptation, concomitant with a decrease in peroxisome-proliferator-activated receptor alpha (PPAR $\alpha$ ) expression $[38,39]$. Moreover, a Western diet triggers toll-like receptor 4 (TLR4)-dependent increase in reactive oxygen species (ROS) production in endothelial cells associated with decreased adiponectin expression in WAT [40]. Free fatty acid (FFA)-dependent TLR4 activation can trigger c-Jun $\mathrm{N}$-terminal kinase (JNK) and the major inflammatory transcription factor, NF- $\mathrm{KB}$, signaling pathways in macrophages and adipocytes, which is associated with enhanced ROS production and oxidative stress [41,42]. High-fat and cafeteria-style diets can exacerbate ROS generation through nicotinamide adenine dinucleotide phosphate (NADPH) oxidase complex up-regulation in multiple tissues, including WAT [32,43]. It has been reported by us and others that high-fat and cafeteria-style diets trigger TNF- $\alpha$-mediated inflammation in animal models $[9,36,44-46]$. Thus, diet-induced obesity is correlated with mitochondrial dysfunction (MD) and endoplasmic reticulum (ER) stress in WAT and liver associated with 
whole-body oxidative stress and the decrease in expression of antioxidant enzymes in the liver [32-36,40,47]. Moreover, it has been established that oxidative stress precedes the onset of high-fat diet (HFD)-induced obesity [32]. Altogether, nutrition transition may be the principal cause of whole-body oxidative stress associated with low-grade inflammation.

\section{Oxidative Stress and Inflammation Interplay in Obesity}

The etiology of obesity is multifactorial. Nevertheless, systemic oxidative stress, resulting from the impaired antioxidant defense system counteracting reactive oxygen species (ROS), is a major hallmark of obesity [17]. Indeed, superoxide anion $\left(\mathrm{O}_{2}{ }^{\bullet-}\right)$ overproduction during obesity can result from protein kinase $C$ (PKC) activation, nicotinamide adenine dinucleotide phosphate (NADPH) oxidase (NOX), glyceraldehyde auto-oxidation and oxidative phosphorylation. Moreover, chronic inflammation has been demonstrated to be associated with oxidative stress in obesity [48]. Protein oxidation and protein misfolding result in adipocyte proteasomal dysfunction [49]. This latter leads to JNK hyperactivation and insulin resistance, mediated by obesity-induced endoplasmic reticulum (ER) stress in the liver [50]. Thus, ROS overproduction during mitochondrial stress is associated with exacerbated inflammation and insulin resistance in adipocytes through the activation of NF$\kappa \mathrm{B}$ [51]. NF- $\mathrm{\kappa B}$ is a transcriptional factor that regulates cytokine gene expression and the inflammatory response, and it can be activated by a variety of stimuli, including dietary or endogenous lipids, hypoxia and gut-derived antigens [16]. Hence, NF- $\kappa$ B seems to serve as a bridge between inflammation and obesity [52]. In addition to NF- $\mathrm{KB}$ signaling, JNK and phospho-inositide 3-kinase (PI3-K) pathways are involved in pro-inflammatory cytokines and adipokines expression and release. The effects of inflammatory cytokines are counteracted by PPAR transcription factors, AMP-activated protein kinase (AMPK), and p38 mitogen-activated protein kinase activation, which are all regulated by adiponectin [52].

Oxidative stress occurs as a result of an imbalance between endogenous ROS production and the natural antioxidant system. As shown in Figure 1, oxidative stress is crucially implicated in the onset of chronic inflammation associated with obesity $[53,54]$. Indeed, it has been reported that obesogenic high-fat Western diets induce a drastic increase in oxidative stress and inflammation associated with insulin resistance and hyperglycemia [55-57]. In fact, high glucose intake increases ROS generation by mononuclear cells and inflammation, revealed by an increase in NF- $\mathrm{B}$ B and activator protein-1 (AP-1) activities in healthy human subjects $[58,59]$. Hyperglycemia constitutes the onset of advanced glycation end products (AGEs)-mediated oxidative stress [60]. Furthermore, the excess of nutrients such as glucose and FFAs leads to the activation of NADPH oxidase (NOX) in adipocytes [61]. NOX, which can also be activated by PKC, triggers adipogenesis in preadipocytes and mediates intracellular ROS generation, particularly of $\mathrm{O}_{2}{ }^{\bullet-}$, in non-phagocytic cells [62-64]. PKC and NOX can, in turn, be activated by $\mathrm{H}_{2} \mathrm{O}_{2}$ in adipocytes [53,65]. In addition to NOX-mediated intracellular ROS production, there is evidence that the mitochondrial respiratory chain is the principal source of cellular ROS, resulting in exacerbated oxidative stress and inflammatory processes in obesity [61,66]. ROS and oxidative stress are known for the activation of stress-activated protein kinases (SAPKs, also referred to as the c-Jun N-terminal kinases, JNKs) [67]. IкB kinase $\beta$ (IKK $\beta$ ) has also been shown to be regulated by oxidative stress and pro-oxidants [68]. After being activated, all of these kinases trigger pro-inflammatory cytokines, chiefly through the nuclear translocation of NF- $\mathrm{KB}$ and AP-1 transcription factors in adipose tissue cells $[69,70]$. It is well known that these proteins regulate gene expression of several oxidant-responsive adipokines such as TNF- $\alpha$, IL-6, monocyte chemoattractant protein-1 (MCP-1), and plasminogen activator inhibitor-1 (PAI1) $[71,72]$. It has been demonstrated that IKK-dependent TNF- $\alpha$ activation downregulates AMPK, which plays a pivotal role in energy homeostasis and modulation of metabolic inflammation [73-75]. Increased AMPK phosphorylation has been correlated with enhanced anti-inflammatory, adiponectin-dependent PPAR $\gamma$ expression and decreased expression of cyclooxygenase 2 (COX-2) and prostaglandin E2 (PGE2) [52,76]. Therefore, it has been suggested that NF-kB-mediated inflammatory pathways in adipocytes involve the activation of 
COX-2 and PGE2 signaling and hypoxia associated with the decrease in anti-inflammatory, adiponectin and PPAR $\gamma$ expression [77,78]. TNF- $\alpha$ and IL-6 secreted from WAT are responsible for the onset of inflammation in other tissues and organs, such as the liver where they enhance hepatic C-reactive protein (CRP) expression [79-81]. Furthermore, circulating MCP-1 (also called CCL2 for chemokine C-C motif ligand 2), which is expressed and secreted from both adipocytes and activated macrophages, promotes monocyte migration and infiltration into WAT across the endothelium [81]. A crosstalk between adipocytes and resident macrophages reinforces oxidative stress through TNF- $\alpha$-mediated ROS generation within WAT cells in an autocrine and paracrine manner [82]. Taken together, all of these events result in local and systemic low-grade inflammation, which can lead to multiple pathogenic outcomes ranging from type 2 diabetes to pro-oncogenic events associated with obesity [83].

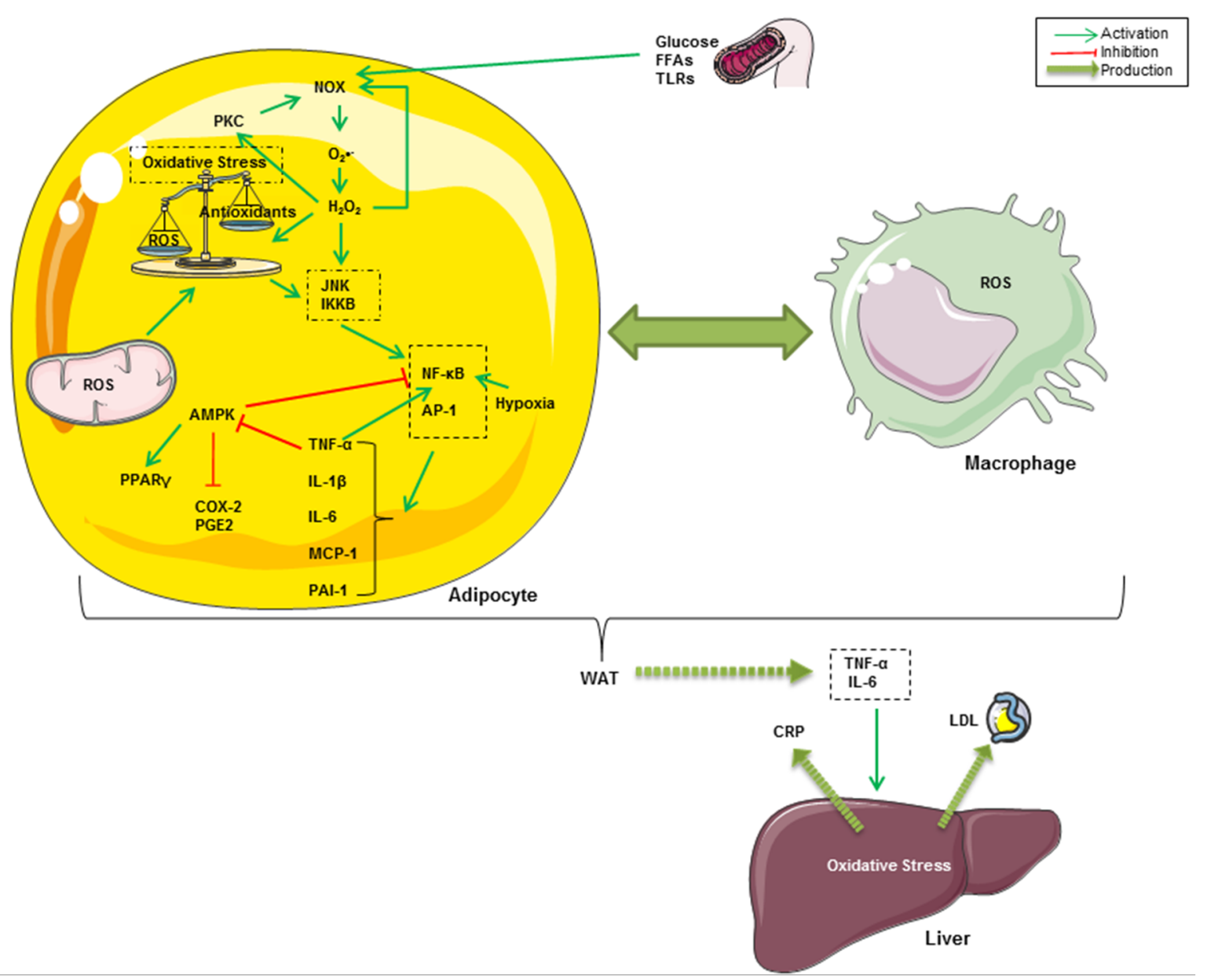

Figure 1. Graphical summary of some inflammatory and oxidative pathways related to obesity. High glucose intake and FFA-dependent TLR4 activation lead to the activation of NOX, which can also be activated by PKC in adipocytes. NOX mediates intracellular ROS generation, mainly $\mathrm{O}_{2}{ }^{\bullet-}$, both in preadipocytes and macrophages. Likewise, mitochondrial ROS exacerbate oxidative stress and inflammatory processes in obesity. JNK mediates ROS and oxidative stress-dependent activation of NF- $\mathrm{kB}$ and AP-1. These latters regulate gene expression of TNF- $\alpha$, IL-6, MCP-1 and PAI-1. The NF- $\mathrm{B}$ pathway might be upregulated in hypoxic adipose tissue and in response to TNF- $\alpha$. Furthermore, TNF- $\alpha$ inhibits AMPK pathways, resulting in increased COX-2 and PGE2 and decreased PPAR $\gamma$. TNF- $\alpha$ and IL- 6 secreted from WAT enhance CRP and low-density lipoprotein (LDL) release from the liver in response to hepatic oxidative stress. A crosstalk between adipocytes and resident macrophages reinforces oxidative stress through TNF- $\alpha$-mediated ROS generation within WAT cells in an autocrine and paracrine manner. 


\section{Polyphenols as the Most Abundant Antioxidant in MedDiet}

Evidence from human studies, generated through a cross-sectional investigation, showed that adherence to the MedDiet is inversely associated with obesity (prevalence ratio $=0.96$ [ [84]. Indeed, a multi-center randomized trial showed that higher adherence to MedDiet is associated with decreased overweight/obesity prevalence, reflected by a lower score of body mass index [85]. Likewise, a recent study conducted on participants with abdominal obesity showed that adherence to MedDiet is associated with low peripheral glucose, total cholesterol and low-density lipoprotein (LDL) cholesterol levels [86]. As far as epigenetics is concerned, MedDiet has been suggested to exhibit positive effects on cardiovascular diseases, including obesity, through the modulation of the circadian locomotor output cycles protein kaput (CLOCK) gene, which is well-known to regulate glucose metabolism [87]. Moreover, NF- $\mathrm{KB}$ has been demonstrated to mediate obesityrelated inflammation [88]. Interestingly, on the basis of a randomized intervention trial, it has been suggested that bioactive polyphenols in MedDiet may improve low-grade chronic inflammatory states [89].

Phenolic compounds or polyphenols are secondary plant metabolites arising biogenetically from either the shikimate/phenylpropanoid pathway or the polyketide acetate/malonate pathway, or both [90]. With more than 8000 molecules, bioavailability and other properties of polyphenols differ from one structure to another [91]. Chemically speaking, the term phenol refers to a homologous series of compounds containing a hydroxyl group bound directly to an aromatic ring. Hence, polyphenols can be defined as substances widely distributed in the plant kingdom with more than one phenyl ring and one or more hydroxyl substituents [92]. Their structure can range from simple compounds, such as phenolic acids and stilbenes, to complex polymers derived from simple substances with high molecular mass, such as tannins (Figure 2) [93]. In the literature, there are multiple classifications of polyphenols from both edible and non-edible plants. However, dietary polyphenols are commonly categorized into two main groups: flavonoid and non-flavonoid polyphenols [94-97]. We have previously shown that polyphenols have antioxidant, antiinflammatory, immunomodulatory, antitumor and anti-obesity properties $[9,10,12-14]$.

Numerous studies have reported that polyphenols are the most abundant antioxidants in MedDiet [91,98-100]. Phenolic acids, such as gallic, ferulic and other hydroxycinnamic acid derivatives, are found in a variety of foods, including olive oil, whole grains, fruits, vegetables, nuts, tea, coffee and red wine $[10,95,101,102]$. Some phenolic acids have been reported to stimulate the secretion of adiponectin and the phosphorylation of AMPK associated with inhibition of NF- $\mathrm{KB}$ activation and macrophage infiltration, resulting in reduced adipogenesis and adipose inflammation in vitro and in obese animals [103-105]. Flavonoids, with about 6000 molecules, are the largest group of polyphenols [106]. These phenolic compounds are found in grains, fruits, vegetables, extra virgin olive oil (EVOO) and beverages such as tea, coffee and red wine [107]. Flavonoids exert prominent antioxidant and anti-inflammatory activities through various mechanisms. In addition to their role in food intake regulation and nutrition absorption, a growing body of evidence supports that flavonoids increase adiponectin and AMPK activation and counteract NF$\mathrm{KB}$ and inducible nitric oxide synthase (iNOS) signaling pathways, resulting in reduced oxidative damage and inflammation associated with obesity [108-111]. Out of the main classes of EVOO polyphenols, hydroxytyrosol and its derivative, oleuropein, have been demonstrated to inhibit low-density lipoprotein (LDL) oxidation in vitro and contribute to management of many metabolic disorders, including obesity, through different mechanisms [112-115]. Stilbenes are a class of polyphenols that chiefly contain resveratrol, which is largely found in grape seeds and red wine. Resveratrol has been shown to be well absorbed across the gastrointestinal tract, even by obese humans [116]. It has been shown that resveratrol inhibits NADPH-induced oxidative stress in RAW 264.7 macrophages [117]. Other studies have shown that resveratrol can increase glutathione peroxidase (GPX) and superoxide dismutase (SOD) expression and activity in animal models, and it modulates gene expression of many antioxidants and anti-inflammatory molecules in obese sub- 
jects $[118,119]$. Common bioavailable phenolic compounds, known for their biological proprieties, in MedDiet are listed in Table 1.

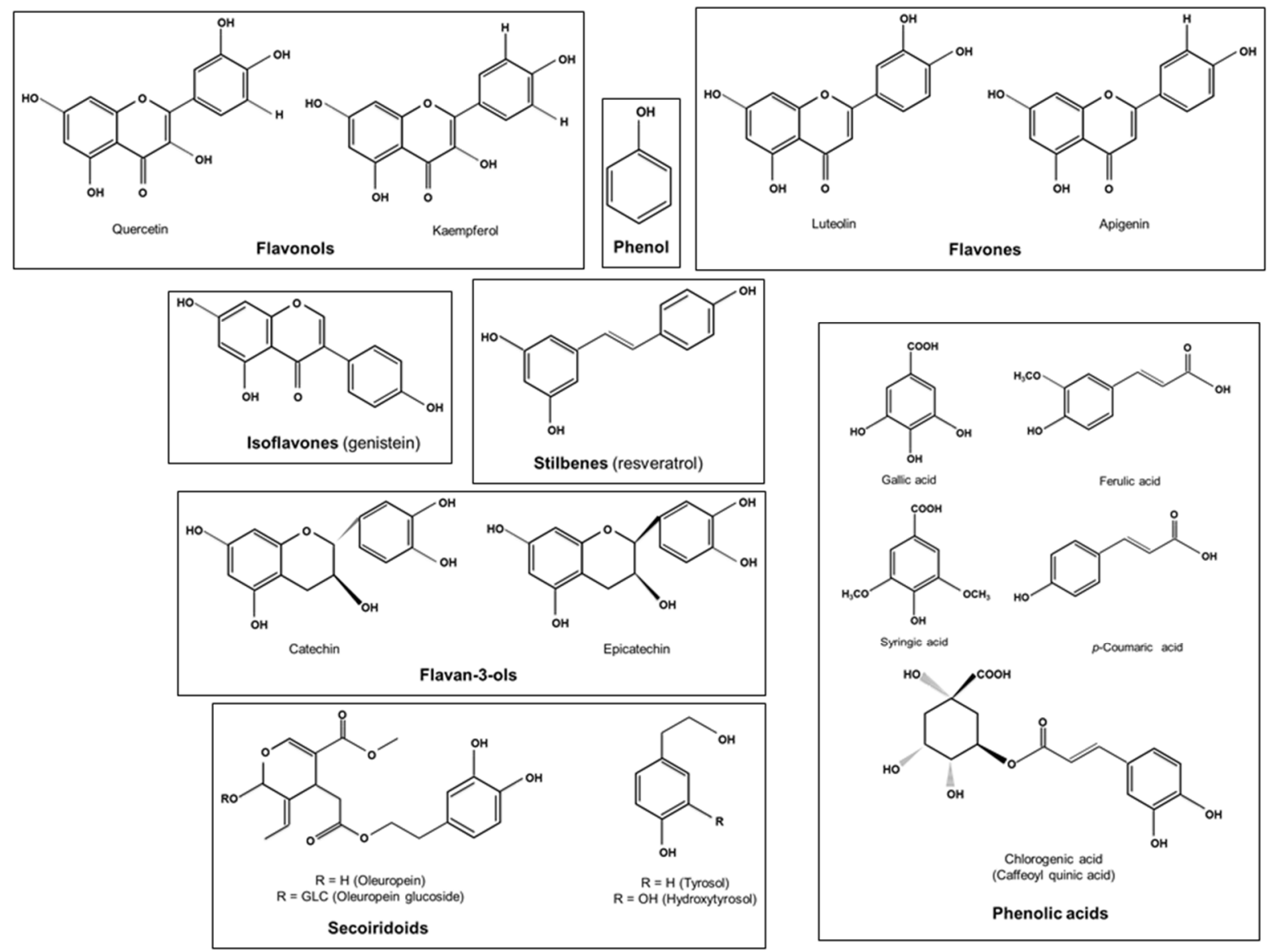

Figure 2. Chemical structure of some dietary polyphenols.

Table 1. Polyphenols commonly found in a Mediterranean-style diet.

\begin{tabular}{|c|c|c|}
\hline & Polyphenols & Principal Dietary Sources \\
\hline \multirow{5}{*}{ Flavonoids } & Flavonols (quercetin, Kaempferol) & $\begin{array}{c}\text { Onions, apples, berries, tea, beans, tomatoes, grapes, } \\
\text { medicinal plants such as Osyris alba root bark, spices such as } \\
\text { coriander seeds }[93,120,121]\end{array}$ \\
\hline & Flavones (apigenin, luteolin) & Black olives, olive oil, wheat grains, fruits, vegetables [91,93] \\
\hline & Isoflavones (genistein) & Bread [122] \\
\hline & Anthocyanidins (anthocyanins) & $\begin{array}{l}\text { Maize, strawberries, blood oranges, pomegranates, beans, red } \\
\text { onions }[93,105]\end{array}$ \\
\hline & Flavanols (catechins, epicatechin) & $\begin{array}{l}\text { Tea, grapes, apples, nuts such as almonds and pistachos, red } \\
\text { wine [93] }\end{array}$ \\
\hline \multirow{4}{*}{ Non-flavonoids } & $\begin{array}{l}\text { Phenolic acids (gallic, ferulic, } p \text {-coumaric, } \\
\text { caffeic syringic, and chlorogenic acid) }\end{array}$ & $\begin{array}{l}\text { Whole cereal grains, tea, carob leaves, Osyris alba root bark, } \\
\text { garlic, spices such as coriander seeds, black cumin seeds, } \\
\text { fenugreek seeds }[10,14,93,105,120,121,123,124]\end{array}$ \\
\hline & Stilbenes (resveratrol) & Grapes, peanuts, plums, beans, red wine $[93,125]$ \\
\hline & Secoiridoids (oleuropein, hydroxytyrosol) & Olive oil $[122,126]$ \\
\hline & Lignans & Whole-grain cereals, olive oil $[93,126]$ \\
\hline
\end{tabular}




\section{MedDiet Polyphenols Counteract Oxidative Stress and Inflammation Associated with Obesity}

Evidence suggests that the management of oxidative stress and inflammation may provide opportunities for the prevention and possible treatment of chronic diseases, including obesity [127]. Therefore, inflammatory and/or ROS-dependent signaling pathways are critical targets of several cardioprotective drugs and antioxidant nutraceuticals, such as polyphenols [128]. Hence, an understanding of the anti-inflammatory effects of a polyphenol-rich MedDiet is fundamental to adopt preventive and therapeutic strategies for diet-related metabolic diseases, including obesity.

It is well established that NOX-mediated oxidative stress can trigger low-grade inflammation [17]. Interestingly, polyphenols from EVOO, the usual component of MedDiet, significantly counteract pro-oxidant enzymes NOX-2 and NOX-4 and mRNA expression in adipocytes, and concomitantly reduce IL- $1 \beta$ and COX-2 mRNA expression and increase the expression of PPAR $\gamma$ mRNA. EVOO polyphenols also attenuate TNF- $\alpha$-induced NF- $\mathrm{B}$ activation [129]. It has been argued that excessive macronutrient-induced endothelial hyperpermeability is crucial to obesity pathogenesis. In fact, in response to cytokines such as MCP-1, endothelial cells facilitate macrophage infiltration into adipose tissue and, ultimately, enable macrophages to promote the inflammatory process [130]. Interestingly, it has been suggested that green tea polyphenol-induced NOX down-regulation contributes to a decrease in ROS production and alleviates endothelial hyperpermeability in HFD-fed rats [131]. Park et al. have demonstrated that resveratrol inhibits NOX1 expression, concomitant with a decrease in ROS generation and MCP-1 mRNA and protein expression. Thereby, it has been suggested that resveratrol abolishes the NOXmediated COX-2/PGE2 pathway in murine resident peritoneal macrophages [132]. In line with these findings, grape polyphenols have been reported to inhibit NOX activation and to activate PPAR $\gamma$, which has been suggested to antagonize NF- $\mathrm{B}$ activation, resulting in attenuated oxidative stress and inflammation associated with obesity [133]. PKC, which can be activated by saturated fatty acids (SFAs), may be an upstream regulator of NOX activity $[63,133,134]$. Therefore, PKC can constitute a therapeutic target for obesity management. Epigallocatechin-3-O-gallate (EGCG), the major catechin found in green tea, has been shown to attenuate inflammation in high glucose-treated endothelial cells through downregulation of PKC and NF- $\kappa B$, which promotes IL- $1 \beta$ and MCP-1 pro-inflammatory cytokines transcription [135]. Quercetin-3-glucoside, which is another tea flavonoid that is found in onions and apples [136,137], has been reported to diminish IL-1 $\beta$ and MCP-1 mRNA expression in TNF- $\alpha$-stimulated human adipocytes [7]. Similarly, $p$-coumaric acid, quercetin and resveratrol curtail TNF- $\alpha$-induced MCP-1 production, which is concomitant with decreased PAI-1 and ROS generation in 3T3-L1 adipocytes. Furthermore, these polyphenols increase the release of adiponectin, glutathione (GSH) and anti-oxidant enzymes, including SOD, GPx and glutathione S-transferase (GST), in 3T3-L1 adipocytes [138].

Nuclear factor erythroid 2 (NF-E2)-related factor 2 (Nrf2) is a transcription factor that has been proposed as a therapeutic target for metabolic syndromes, including obesity, due to its mediation in triggering metabolic regulators such as PPAR $\gamma$ and antioxidant response element (ARE) in the liver and WAT [139]. Quercetin, which is one of the two main representative molecules of the flavonol subgroup [93], activates Nrf2 in RAW264.7 macrophages [140]. This activation of Nrf2 is accompanied by inhibition of the NF- $\mathrm{B}$ pathway, and decreased mRNA expression of TNF- $\alpha$, iNOS, IL-1 $\beta$, IL-6 and macrophage inflammatory protein $1 \alpha(\mathrm{MIP} 1 \alpha)$. An in vivo study revealed that quercetin reduces the concentration of serum inflammation biomarkers (CRP and PAI-1) in obese mice [141]. Luteolin, abundantly present in MedDiet, has been found to exert anti-inflammatory activity through inhibiting NF-KB and AP-1 pathways, leading to the suppression of TNF- $\alpha$, IL-6, iNOS and COX-2 gene expression in macrophages [142].

A growing body of evidence indicates that AMPK plays a pivotal role in regulating whole-body metabolism, including obesity-related metabolic-inflammation [75]. It has 
been reported that altered AMPK activation by phosphorylation is associated with inflammatory states in both mouse models of obesity and in obese subjects [143,144]. Indeed, it has been observed that both inflammation and oxidative stress are improved partly through adiponectin/AMPK pathways. Therefore, AMPK has been considered as an attractive therapeutic target for obesity management [20]. Ferulic acid, largely found in whole grains, has been shown to exert anti-obesity activity through the upregulation of AMPK phosphorylation, which is accompanied by a decrease in whole-body oxidative stress and inflammation - evidenced by decreased ROS generation, pro-inflammatory cytokines production, adhesion molecules expression, and circulating LDL levels-and increased adiponectin expression and circulating high-density lipoprotein (HDL) levels in HFD-fed obese mice [105]. Likewise, AMPK signaling partially mediates resveratroldependent anti-oxidant effects through reversing mitochondrial dysfunction, increasing total antioxidative capability, elevating activity of SOD and GPx and curtailing malondialdehyde (MDA) and carbonyl protein contents in HFD-fed obese mice [145]. Consistent with these observations, resveratrol inhibits NF- $\mathrm{KB}$ activation, resulting in reduced TNF- $\alpha$, IL-1 $\beta$, IL-6, and COX-2 mRNA expression, and reduced IL-6 and PGE2 secretion in 3T3L1-derived adipocytes [146]. Hydroxytyrosol has been reported to modulate oxidative stress and inflammation associated with obesity. Indeed, hydroxytyrosol increases AMPK activation, Nrf2 and PPAR $\gamma$ mRNA expression, and adiponectin expression in adipocytes, and decreases PGE2 expression, VCAM-1 vascular cell adhesion protein expression and circulating CRP inflammatory marker [3]. Altogether, MedDiet's phenolic compounds can modulate oxidative stress and inflammation associated with obesity through different mechanisms that are most likely orchestrated by NOX, AMPK, NF-kB, PKC and Nrf2 signaling (Figure 3).

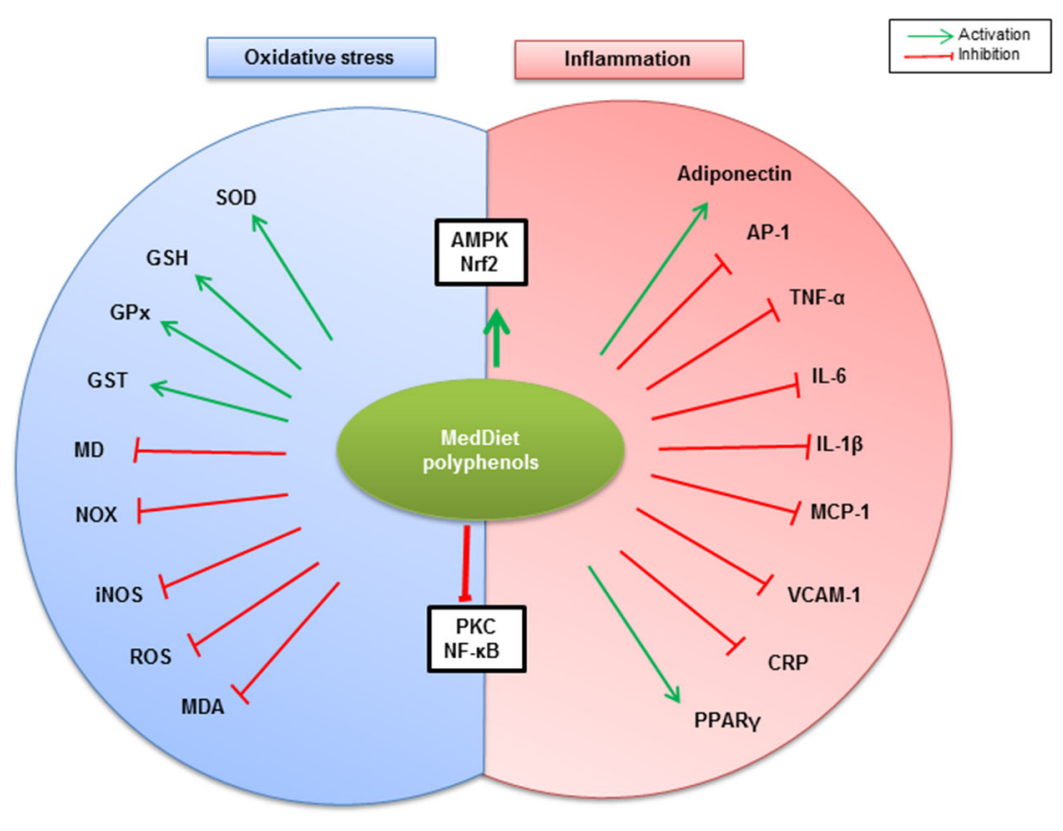

Figure 3. Summary of potential mechanisms by which MedDiet polyphenols modulate oxidative stress and inflammation associated with obesity. MedDiet polyphenols potentiate both AMPKand Nrf2-mediated anti-inflammatory and antioxidant pathways, reflected by anti-inflammatory adiponectin, PPAR $\gamma$, and endogenous antioxidants (SOD, GSH, GPx, and GST) upregulation. On the other hand, PKC and NF-kB-dependent inflammation and oxidative stress are counteracted by MedDiet polyphenols, reflected by the downregulation of pro-inflammatory molecules (AP-1, TNF- $\alpha$, IL-6, IL-1 $\beta$, MCP-1, VCAM-1, and CRP), and oxidative stress mediators and operators (MD, NOX, iNOS, ROS, MDA). 


\section{Concluding Remarks}

A Mediterranean-style dietary pattern is effective in managing nutrition transitionrelated metabolic disorders, including obesity. Among the antioxidant nutraceuticals of MedDiet, polyphenols exhibit antioxidant and anti-inflammatory properties. Hydroxycinnamic acids, flavonoids (chiefly quercetin and catechins), resveratrol, oleuropein and hydroxytyrosol are the most studied phenolic compounds. MedDiet polyphenols alleviate inflammation and oxidative stress in obesity, in part, through the regulation of AMPK and NF-kB signaling pathways. Hence, targeting these pathways may be a prominent therapeutic approach for managing obesity.

Author Contributions: A.H. and N.A.K. conceptualized this review. A.N. searched the literature and drafted the manuscript. A.H., N.A.K., A.S.K. and B.M. revised and finalized the manuscript. All authors have read and agreed to the published version of the manuscript.

Funding: The study was supported by Labex LipSTIC INSERM U1231 University of Burgundy, France. The funders had no role in study design, data collection and analysis, decision to publish, or preparation of the manuscript.

Conflicts of Interest: The authors declare no conflict of interest.

\section{Abbreviations}

\begin{tabular}{|c|c|}
\hline AMPK & AMP-activated protein kinase \\
\hline AP-1 & activator protein-1 \\
\hline ARE & Antioxidant Response Element \\
\hline COX-2 & cyclooxygenase 2 \\
\hline CRP & C-reactive protein \\
\hline EGCG & Epigallocatechin-3-O-gallate \\
\hline ER & Endoplasmic Reticulum \\
\hline EVOO & extra virgin olive oil \\
\hline FFAs & free fatty acids \\
\hline GPx & glutathione peroxidase \\
\hline GSH & glutathione \\
\hline GST & glutathione $S$-transferase \\
\hline HDL & high-density lipoprotein \\
\hline HFD & high fat diet \\
\hline IKK & IкB kinase \\
\hline IL & interleukin \\
\hline iNOS & inducible nitric oxide synthase \\
\hline $\mathrm{I} \kappa \mathrm{B}$ & Inhibitor of $\mathrm{kB}$ \\
\hline JNK & c-Jun N-terminal kinase \\
\hline LDL & low-density lipoprotein \\
\hline MCP-1 & monocyte chemoattractant protein-1 \\
\hline MD & mitochondrial dysfunction \\
\hline MDA & malondialdehyde \\
\hline MedDiet & Mediterranean diet \\
\hline $\mathrm{MIP} 1 \alpha$ & macrophage inflammatory protein $1 \alpha$ \\
\hline NF- $k B$ & nuclear factor-kappa B \\
\hline NOX & nicotinamide adenine dinucleotide phosphate (NADPH) oxidase \\
\hline Nrf2 & Nuclear factor erythroid 2 (NF-E2)-related factor 2 \\
\hline PAI-1 & plasminogen activator inhibitor-1 \\
\hline PGE2 & prostaglandin E2 \\
\hline PI3-K & phospho-inositide 3-kinase \\
\hline PKC & protein kinase $\mathrm{C}$ \\
\hline PPAR & peroxisome proliferator-activated receptor \\
\hline ROS & reactive oxygen species \\
\hline SAPKs & Stress-Activated Protein Kinases \\
\hline SFAs & saturated fatty acids \\
\hline
\end{tabular}




$\begin{array}{ll}\text { SOD } & \text { superoxide dismutase } \\ \text { TLR } & \text { Toll-like receptor } \\ \text { TNF- } \alpha & \text { tumor necrosis factor-alpha } \\ \text { VCAM-1 } & \text { vascular cell adhesion molecule-1 } \\ \text { WAT } & \text { white adipose tissue. }\end{array}$

\section{References}

1. Romagnolo, D.F.; Selmin, O.I. Mediterranean diet and prevention of chronic diseases. Nutr. Today 2017, 52, 208. [CrossRef] [PubMed]

2. Davis, C.; Bryan, J.; Hodgson, J.; Murphy, K. Definition of the mediterranean diet: A literature review. Nutrients 2015, 7, 9139-9153. [CrossRef]

3. Peyrol, J.; Riva, C.; Amiot, M.J. Hydroxytyrosol in the prevention of the metabolic syndrome and related disorders. Nutrients 2017, 9, 306. [CrossRef]

4. Ragaee, S.; Abdel-Aal, E.-S.M.; Noaman, M. Antioxidant activity and nutrient composition of selected cereals for food use. Food Chem. 2006, 98, 32-38. [CrossRef]

5. Sakakibara, H.; Honda, Y.; Nakagawa, S.; Ashida, H.; Kanazawa, K. Simultaneous determination of all polyphenols in vegetables, fruits, and teas. J. Agric. Food Chem. 2003, 51, 571-581. [CrossRef] [PubMed]

6. Vinson, J.A.; Cai, Y. Nuts, especially walnuts, have both antioxidant quantity and efficacy and exhibit significant potential health benefits. Food Funct. 2012, 3, 134-140. [CrossRef] [PubMed]

7. Corrêa, T.A.F.; Rogero, M.M. Polyphenols regulating microRNAs and inflammation biomarkers in obesity. Nutrition 2019, 59, 150-157. [CrossRef]

8. Jin, T.; Song, Z.; Weng, J.; Fantus, I.G. Curcumin and other dietary polyphenols: Potential mechanisms of metabolic actions and therapy for diabetes and obesity. Am. J. Physiol. Metab. 2018, 314, E201-E205. [CrossRef] [PubMed]

9. Aboura, I.; Nani, A.; Belarbi, M.; Murtaza, B.; Fluckiger, A.; Dumont, A.; Benammar, C.; Tounsi, M.S.; Ghiringhelli, F.; Rialland, M.; et al. Protective effects of polyphenol-rich infusions from carob (Ceratonia siliqua) leaves and cladodes of Opuntia ficus-indica against inflammation associated with diet-induced obesity and DSS-induced colitis in Swiss mice. Biomed. Pharmacother. 2017, 96, 1022-1035. [CrossRef]

10. Nani, A.; Belarbi, M.; Ksouri-Megdiche, W.; Abdoul-Azize, S.; Benammar, C.; Ghiringhelli, F.; Hichami, A.; Khan, N.A. Effects of polyphenols and lipids from Pennisetum glaucum grains on T-cell activation: Modulation of Ca2+ and ERK1/ERK2 signaling. BMC Complement. Altern. Med. 2015, 15, 426. [CrossRef] [PubMed]

11. Karam, B.S.; Moreno, A.C.; Koh, W.; Akar, J.G.; Akar, F.G. Oxidative stress and inflammation as central mediators of atrial fibrillation in obesity and diabetes. Cardiovasc. Diabetol. 2017, 17-20. [CrossRef]

12. Nani, A.; Belarbi, M.; Murtaza, B.; Benammar, C.; Merghoub, T.; Rialland, M.; Akhtar Khan, N.; Hichami, A. Polyphenols from Pennisetum glaucum grains induce MAP kinase phosphorylation and cell cycle arrest in human osteosarcoma cells. J. Funct. Foods 2019, 54, 422-432. [CrossRef]

13. Zeriouh, W.; Nani, A.; Belarbi, M.; Dumont, A.; de Rosny, C.; Aboura, I.; Ghanemi, F.Z.; Murtaza, B.; Patoli, D.; Thomas, C. Correction: Phenolic extract from oleaster (Olea europaea var. Sylvestris) leaves reduces colon cancer growth and induces caspase-dependent apoptosis in colon cancer cells via the mitochondrial apoptotic pathway. PLoS ONE 2017, 12, e0176574. [CrossRef]

14. Ghanemi, F.Z.; Belarbi, M.; Fluckiger, A.; Nani, A.; Dumont, A.; De Rosny, C.; Aboura, I.; Khan, A.S.; Murtaza, B.; Benammar, C.; et al. Carob leaf polyphenols trigger intrinsic apoptotic pathway and induce cell cycle arrest in colon cancer cells. J. Funct. Foods 2017, 33, 112-121. [CrossRef]

15. Blaak, E.E. Current metabolic perspective on malnutrition in obesity: Towards more subgroup-based nutritional approaches? Proc. Nutr. Soc. 2020, 1-7. [CrossRef] [PubMed]

16. Reilly, S.M.; Saltiel, A.R. Adapting to obesity with adipose tissue inflammation. Nat. Rev. Endocrinol. 2017, 13, 633-643. [CrossRef] [PubMed]

17. Engin, A. The pathogenesis of obesity-associated adipose tissue inflammation. In Obesity and lipotoxicity; Springer: Berlin/Heidelberg, Germany, 2017; pp. 221-245.

18. Landecho, M.F.; Tuero, C.; Valentí, V.; Bilbao, I.; de la Higuera, M.; Frühbeck, G. Relevance of Leptin and Other Adipokines in Obesity-Associated Cardiovascular Risk. Nutrients 2019, 11, 2664. [CrossRef]

19. Narayanaswami, V.; Dwoskin, L.P. Obesity: Current and potential pharmacotherapeutics and targets. Pharmacol. Ther. 2017, 170, 116-147. [CrossRef]

20. Gasparrini, M.; Giampieri, F.; Suarez, J.A.; Mazzoni, L.; Forbes Hernandez, T.Y.; Quiles, J.L.; Bullon, P.; Battino, M. AMPK as a new attractive therapeutic target for disease prevention: The role of dietary compounds AMPK and disease prevention. Curr. Drug Targets 2016, 17, 865-889. [CrossRef]

21. Cao, C.; Pathak, S.; Patil, K. Antioxidant Nutraceuticals: Preventive and Healthcare Applications; CRC Press: Boca Raton, FL, USA, 2018.

22. Hwang, J.-T.; Kwon, D.Y.; Yoon, S.H. AMP-activated protein kinase: A potential target for the diseases prevention by natural occurring polyphenols. N. Biotechnol. 2009, 26, 17-22. [CrossRef] 
23. Meydani, M.; Hasan, S.T. Dietary polyphenols and obesity. Nutrients 2010, 2, 737-751. [CrossRef]

24. Mohamed, G.A.; Ibrahim, S.R.M.; Elkhayat, E.S.; El Dine, R.S. Natural anti-obesity agents. Bull. Fac. Pharm. Cairo Univ. 2014, 52, 269-284. [CrossRef]

25. Wang, S.; Moustaid-Moussa, N.; Chen, L.; Mo, H.; Shastri, A.; Su, R.; Bapat, P.; Kwun, I.; Shen, C.-L. Novel insights of dietary polyphenols and obesity. J. Nutr. Biochem. 2014, 25, 1-18. [CrossRef] [PubMed]

26. Castro-Barquero, S.; Lamuela-Raventós, R.M.; Doménech, M.; Estruch, R. Relationship between Mediterranean dietary polyphenol intake and obesity. Nutrients 2018, 10, 1523. [CrossRef]

27. Dludla, P.V.; Nkambule, B.B.; Jack, B.; Mkandla, Z.; Mutize, T.; Silvestri, S.; Orlando, P.; Tiano, L.; Louw, J.; Mazibuko-Mbeje, S.E. Inflammation and oxidative stress in an obese state and the protective effects of gallic acid. Nutrients 2019, 11, 23. [CrossRef] [PubMed]

28. Ramadori, G.; Gautron, L.; Fujikawa, T.; Vianna, C.R.; Elmquist, J.K.; Coppari, R. Central administration of resveratrol improves diet-induced diabetes. Endocrinology 2009, 150, 5326-5333. [CrossRef] [PubMed]

29. Christ, A.; Lauterbach, M.; Latz, E. Western diet and the immune system: An inflammatory connection. Immunity 2019, 51, 794-811. [CrossRef]

30. Nasreddine, L.M.; Kassis, A.N.; Ayoub, J.J.; Naja, F.A.; Hwalla, N.C. Nutritional status and dietary intakes of children amid the nutrition transition: The case of the Eastern Mediterranean Region. Nutr. Res. 2018, 57, 12-27. [CrossRef]

31. Bortolin, R.C.; Vargas, A.R.; Gasparotto, J.; Chaves, P.R.; Schnorr, C.E.; Martinello, K.B.; Silveira, A.K.; Rabelo, T.K.; Gelain, D.P.; Moreira, J.C.F. A new animal diet based on human Western diet is a robust diet-induced obesity model: Comparison to high-fat and cafeteria diets in term of metabolic and gut microbiota disruption. Int. J. Obes. 2018, 42, 525-534. [CrossRef]

32. Matsuzawa-Nagata, N.; Takamura, T.; Ando, H.; Nakamura, S.; Kurita, S.; Misu, H.; Ota, T.; Yokoyama, M.; Honda, M.; Miyamoto, K. Increased oxidative stress precedes the onset of high-fat diet-induced insulin resistance and obesity. Metabolism 2008, 57, 1071-1077. [CrossRef] [PubMed]

33. Yuzefovych, L.V.; Musiyenko, S.I.; Wilson, G.L.; Rachek, L.I. Mitochondrial DNA damage and dysfunction, and oxidative stress are associated with endoplasmic reticulum stress, protein degradation and apoptosis in high fat diet-induced insulin resistance mice. PLoS ONE 2013, 8, e54059. [CrossRef]

34. Carillon, J.; Romain, C.; Bardy, G.; Fouret, G.; Feillet-Coudray, C.; Gaillet, S.; Lacan, D.; Cristol, J.-P.; Rouanet, J.-M. Cafeteria diet induces obesity and insulin resistance associated with oxidative stress but not with inflammation: Improvement by dietary supplementation with a melon superoxide dismutase. Free Radic. Biol. Med. 2013, 65, 254-261. [CrossRef] [PubMed]

35. Johnson, A.R.; Wilkerson, M.D.; Sampey, B.P.; Troester, M.A.; Hayes, D.N.; Makowski, L. Cafeteria diet-induced obesity causes oxidative damage in white adipose. Biochem. Biophys. Res. Commun. 2016, 473, 545-550. [CrossRef] [PubMed]

36. Gil-Cardoso, K.; Ginés, I.; Pinent, M.; Ardévol, A.; Terra, X.; Blay, M. A cafeteria diet triggers intestinal inflammation and oxidative stress in obese rats. Br. J. Nutr. 2017, 117, 218-229. [CrossRef]

37. Kopp, W. How western diet and lifestyle drive the pandemic of obesity and civilization diseases. Diabetes Metab. Syndr. Obes. Targets Ther. 2019, 12, 2221. [CrossRef] [PubMed]

38. Wilson, C.R.; Tran, M.K.; Salazar, K.L.; Young, M.E.; Taegtmeyer, H. Western diet, but not high fat diet, causes derangements of fatty acid metabolism and contractile dysfunction in the heart of Wistar rats. Biochem. J. 2007, 406, 457-467. [CrossRef] [PubMed]

39. Neves, F.A.; Cortez, E.; Bernardo, A.F.; Mattos, A.B.M.; Vieira, A.K.; de O Malafaia, T.; Thole, A.A.; C de S Rodrigues-Cunha, A.; Garcia-Souza, É.P.; Sichieri, R. Heart energy metabolism impairment in Western-diet induced obese mice. J. Nutr. Biochem. 2014, 25, 50-57. [CrossRef] [PubMed]

40. Kramer, B.; França, L.M.; Zhang, Y.; de Aandrade Paes, A.M.; Gerdes, A.M.; Carrillo-Sepulveda, M.A. Western diet triggers Toll-like receptor 4 signaling-induced endothelial dysfunction in female Wistar rats. Am. J. Physiol. Circ. Physiol. 2018, 315, H1735-H1747. [CrossRef]

41. Zeyda, M.; Stulnig, T.M. Obesity, inflammation, and insulin resistance-A mini-review. Gerontology 2009, 55, 379-386. [CrossRef]

42. Nguyen, M.T.A.; Favelyukis, S.; Nguyen, A.-K.; Reichart, D.; Scott, P.A.; Jenn, A.; Liu-Bryan, R.; Glass, C.K.; Neels, J.G.; Olefsky, J.M. A subpopulation of macrophages infiltrates hypertrophic adipose tissue and is activated by free fatty acids via Toll-like receptors 2 and 4 and JNK-dependent pathways. J. Biol. Chem. 2007, 282, 35279-35292. [CrossRef]

43. Jiang, F.; Lim, H.K.; Morris, M.J.; Prior, L.; Velkoska, E.; Wu, X.; Dusting, G.J. Systemic upregulation of NADPH oxidase in diet-induced obesity in rats. Redox Rep. 2011, 16, 223-229. [CrossRef]

44. Borst, S.E.; Conover, C.F. High-fat diet induces increased tissue expression of TNF- $\alpha$. Life Sci. 2005, 77, 2156-2165. [CrossRef] [PubMed]

45. Haidar; Soeatmadji, D.W. Effects of high-carbohydrate and high fat diet on formation of foam cells and expression of TNF-alpha in Rattus novergicus. Acta Med. Indones. 2007, 39, 119-123. [PubMed]

46. Sampey, B.P.; Vanhoose, A.M.; Winfield, H.M.; Freemerman, A.J.; Muehlbauer, M.J.; Fueger, P.T.; Newgard, C.B.; Makowski, L. Cafeteria diet is a robust model of human metabolic syndrome with liver and adipose inflammation: Comparison to high-fat diet. Obesity 2011, 19, 1109-1117. [CrossRef]

47. Heinonen, I.; Rinne, P.; Ruohonen, S.T.; Ruohonen, S.; Ahotupa, M.; Savontaus, E. The effects of equal caloric high fat and western diet on metabolic syndrome, oxidative stress and vascular endothelial function in mice. Acta Physiol. 2014, 211, 515-527. [CrossRef] [PubMed] 
48. Manna, P.; Jain, S.K. Obesity, oxidative stress, adipose tissue dysfunction, and the associated health risks: Causes and therapeutic strategies. Metab. Syndr. Relat. Disord. 2015, 13, 423-444. [CrossRef]

49. Diaz-Ruiz, A.; Guzman-Ruiz, R.; Moreno, N.R.; Garcia-Rios, A.; Delgado-Casado, N.; Membrives, A.; Túnez, I.; El Bekay, R.; Fernández-Real, J.M.; Tovar, S. Proteasome dysfunction associated to oxidative stress and proteotoxicity in adipocytes compromises insulin sensitivity in human obesity. Antioxid. Redox Signal. 2015, 23, 597-612. [CrossRef]

50. Otoda, T.; Takamura, T.; Misu, H.; Ota, T.; Murata, S.; Hayashi, H.; Takayama, H.; Kikuchi, A.; Kanamori, T.; Shima, K.R. Proteasome dysfunction mediates obesity-induced endoplasmic reticulum stress and insulin resistance in the liver. Diabetes 2013, 62, 811-824. [CrossRef]

51. Hurrle, S.; Hsu, W.H. The etiology of oxidative stress in insulin resistance. Biomed. J. 2017, 40, 257-262. [CrossRef] [PubMed]

52. Gil, A.; Aguilera, C.M.; Gil-Campos, M.; Canete, R. Altered signalling and gene expression associated with the immune system and the inflammatory response in obesity. Br. J. Nutr. 2007, 98, S121-S126. [CrossRef]

53. Furukawa, S.; Fujita, T.; Shimabukuro, M.; Iwaki, M.; Yamada, Y.; Nakajima, Y.; Nakayama, O.; Makishima, M.; Matsuda, M.; Shimomura, I. Increased oxidative stress in obesity and its impact on metabolic syndrome. J. Clin. Investig. 2017, 114, 1752-1761. [CrossRef] [PubMed]

54. Maslov, L.N.; Naryzhnaya, N.V.; Boshchenko, A.A.; Popov, S.V.; Ivanov, V.V.; Oeltgen, P.R. Is oxidative stress of adipocytes a cause or a consequence of the metabolic syndrome? J. Clin. Transl. Endocrinol. 2019, 15, 1-5. [CrossRef]

55. Patel, C.; Ghanim, H.; Ravishankar, S.; Sia, C.L.; Viswanathan, P.; Mohanty, P.; Dandona, P. Prolonged reactive oxygen species generation and nuclear factor- $\mathrm{kB}$ activation after a high-fat, high-carbohydrate meal in the obese. J. Clin. Endocrinol. Metab. 2007, 92, 4476-4479. [CrossRef]

56. Ballal, K.; Wilson, C.R.; Harmancey, R.; Taegtmeyer, H. Obesogenic high fat western diet induces oxidative stress and apoptosis in rat heart. Mol. Cell. Biochem. 2010, 344, 221-230. [CrossRef] [PubMed]

57. Bondia-Pons, I.; Ryan, L.; Martinez, J.A. Oxidative stress and inflammation interactions in human obesity. J. Physiol. Biochem. 2012, 68, 701-711. [CrossRef]

58. Aljada, A.; Ghanim, H.; Mohanty, P.; Syed, T.; Bandyopadhyay, A.; Dandona, P. Glucose intake induces an increase in activator protein 1 and early growth response 1 binding activities, in the expression of tissue factor and matrix metalloproteinase in mononuclear cells, and in plasma tissue factor and matrix metalloproteinase concentrations. Am. J. Clin. Nutr. 2004, 80, 51-57. [PubMed]

59. Aljada, A.; Friedman, J.; Ghanim, H.; Mohanty, P.; Hofmeyer, D.; Chaudhuri, A.; Dandona, P. Glucose ingestion induces an increase in intranuclear nuclear factor kappaB, a fall in cellular inhibitor kappaB, and an increase in tumor necrosis factor alpha messenger RNA by mononuclear cells in healthy human subjects. Metabolism 2006, 55, 1177-1185. [CrossRef]

60. Nowotny, K.; Jung, T.; Höhn, A.; Weber, D.; Grune, T. Advanced glycation end products and oxidative stress in type 2 diabetes mellitus. Biomolecules 2015, 5, 194-222. [CrossRef]

61. Han, C.Y.; Umemoto, T.; Omer, M.; Den Hartigh, L.J.; Chiba, T.; LeBoeuf, R.; Buller, C.L.; Sweet, I.R.; Pennathur, S.; Abel, E.D. NADPH oxidase-derived reactive oxygen species increases expression of monocyte chemotactic factor genes in cultured adipocytes. J. Biol. Chem. 2012, 287, 10379-10393. [CrossRef] [PubMed]

62. Mouche, S.; Mkaddem, S.B.; Wang, W.; Katic, M.; Tseng, Y.-H.; Carnesecchi, S.; Steger, K.; Foti, M.; Meier, C.A.; Muzzin, P. Reduced expression of the NADPH oxidase NOX4 is a hallmark of adipocyte differentiation. Biochim. Biophys. Acta (BBA) Mol. Cell Res. 2007, 1773, 1015-1027. [CrossRef]

63. Beaudeux, J.-L.; Peynet, J.; Bonnefont-Rousselot, D.; Therond, P.; Delattre, J.; Legrand, A. Sources cellulaires des espèces réactives de l'oxygène et de l'azote: Implication dans la transcription et la régulation des gènes. In Annales Pharmaceutiques Françaises; Elsevier: Amsterdam, The Netherlands, 2006; Volume 64, pp. 373-381.

64. Giorgi, C.; Agnoletto, C.; Baldini, C.; Bononi, A.; Bonora, M.; Marchi, S.; Missiroli, S.; Patergnani, S.; Poletti, F.; Rimessi, A. Redox control of protein kinase C: Cell-and disease-specific aspects. Antioxid. Redox Signal. 2010, 13, 1051-1085. [CrossRef]

65. Talior, I.; Yarkoni, M.; Bashan, N.; Eldar-Finkelman, H. Increased glucose uptake promotes oxidative stress and PKC- $\delta$ activation in adipocytes of obese, insulin-resistant mice. Am. J. Physiol. Metab. 2003, 285, E295-E302. [CrossRef]

66. De Mello, A.H.; Costa, A.B.; Engel, J.D.G.; Rezin, G.T. Mitochondrial dysfunction in obesity. Life Sci. 2018, 192, 26-32. [CrossRef]

67. Kyriakis, J.M.; Avruch, J. Protein kinase cascades activated by stress and inflammatory cytokines. Bioessays 1996, 18, 567-577. [CrossRef]

68. Karin, M.; Takahashi, T.; Kapahi, P.; Delhase, M.; Chen, Y.; Makris, C.; Rothwarf, D.; Baud, V.; Natoli, G.; Guido, F. Oxidative stress and gene expression: The AP-1 and NF- $\kappa$ B connections. Biofactors 2001, 15, 87-89. [CrossRef] [PubMed]

69. Monteiro, R.; Azevedo, I. Chronic inflammation in obesity and the metabolic syndrome. Mediat. Inflamm. 2010, 2010. [CrossRef]

70. Nandipati, K.C.; Subramanian, S.; Agrawal, D.K. Protein kinases: Mechanisms and downstream targets in inflammation-mediated obesity and insulin resistance. Mol. Cell. Biochem. 2017, 426, 27-45. [CrossRef] [PubMed]

71. Kamigaki, M.; Sakaue, S.; Tsujino, I.; Ohira, H.; Ikeda, D.; Itoh, N.; Ishimaru, S.; Ohtsuka, Y.; Nishimura, M. Oxidative stress provokes atherogenic changes in adipokine gene expression in 3T3-L1 adipocytes. Biochem. Biophys. Res. Commun. 2006, 339, 624-632. [CrossRef]

72. Roebuck, K.A. Oxidant stress regulation of IL-8 and ICAM-1 gene expression: Differential activation and binding of the transcription factors AP-1 and NF-kappaB. Int. J. Mol. Med. 1999, 4, 223-253. [CrossRef] [PubMed] 
73. Lyons, C.L.; Kennedy, E.B.; Roche, H.M. Metabolic inflammation-differential modulation by dietary constituents. Nutrients 2016, 8, 247. [CrossRef]

74. Ruderman, N.B.; Carling, D.; Prentki, M.; Cacicedo, J.M. AMPK, insulin resistance, and the metabolic syndrome. J. Clin. Investig. 2013, 123, 2764-2772. [CrossRef]

75. Lyons, C.L.; Roche, H.M. Nutritional modulation of AMPK-impact upon metabolic-inflammation. Int. J. Mol. Sci. 2018, 19, 3092. [CrossRef]

76. Huang, B.-P.; Lin, C.-H.; Chen, H.-M.; Lin, J.-T.; Cheng, Y.-F.; Kao, S.-H. AMPK activation inhibits expression of proinflammatory mediators through downregulation of PI3K/p38 MAPK and NF-KB signaling in murine macrophages. DNA Cell Biol. 2015, 34, 133-141. [CrossRef]

77. Inazumi, T.; Shirata, N.; Morimoto, K.; Takano, H.; Segi-Nishida, E.; Sugimoto, Y. Prostaglandin E2-EP4 signaling suppresses adipocyte differentiation in mouse embryonic fibroblasts via an autocrine mechanism. J. Lipid Res. 2011, 52, 1500-1508. [CrossRef] [PubMed]

78. Chan, P.-C.; Hsiao, F.-C.; Chang, H.-M.; Wabitsch, M.; Hsieh, P.S. Importance of adipocyte cyclooxygenase-2 and prostaglandin E2-prostaglandin E receptor 3 signaling in the development of obesity-induced adipose tissue inflammation and insulin resistance. FASEB J. 2016, 30, 2282-2297. [CrossRef]

79. Bulló, M.; García-Lorda, P.; Megias, I.; Salas-Salvadó, J. Systemic inflammation, adipose tissue tumor necrosis factor, and leptin expression. Obes. Res. 2003, 11, 525-531. [CrossRef] [PubMed]

80. Maachi, M.; Pieroni, L.; Bruckert, E.; Jardel, C.; Fellahi, S.; Hainque, B.; Capeau, J.; Bastard, J.P. Systemic low-grade inflammation is related to both circulating and adipose tissue TNF $\alpha$, leptin and IL-6 levels in obese women. Int. J. Obes. 2004, 28, 993-997. [CrossRef]

81. Shoelson, S.E.; Herrero, L.; Naaz, A. Obesity, inflammation, and insulin resistance. Gastroenterology 2007, 132, 2169-2180. [CrossRef] [PubMed]

82. Hahn, W.S.; Kuzmicic, J.; Burrill, J.S.; Donoghue, M.A.; Foncea, R.; Jensen, M.D.; Lavandero, S.; Arriaga, E.A.; Bernlohr, D.A. Proinflammatory cytokines differentially regulate adipocyte mitochondrial metabolism, oxidative stress, and dynamics. Am. J. Physiol. Metab. 2014, 306, E1033-E1045. [CrossRef]

83. Villarroya, F.; Cereijo, R.; Gavaldà-Navarro, A.; Villarroya, J.; Giralt, M. Inflammation of brown/beige adipose tissues in obesity and metabolic disease. J. Intern. Med. 2018, 284, 492-504. [CrossRef]

84. Álvarez-Álvarez, I.; Martínez-González, M.Á.; Sánchez-Tainta, A.; Corella, D.; Díaz-López, A.; Fitó, M.; Vioque, J.; Romaguera, D.; Martínez, J.A.; Wärnberg, J. Adherence to an energy-restricted Mediterranean diet score and prevalence of cardiovascular risk factors in the PREDIMED-plus: A cross-sectional study. Rev. Española Cardiol. Engl. Ed. 2019, 72, 925-934. [CrossRef]

85. Galilea-Zabalza, I.; Buil-Cosiales, P.; Salas-Salvadó, J.; Toledo, E.; Ortega-Azorín, C.; Díez-Espino, J.; Vázquez-Ruiz, Z.; Zomeño, M.D.; Vioque, J.; Martínez, J.A. Mediterranean diet and quality of life: Baseline cross-sectional analysis of the PREDIMED-PLUS trial. PLoS ONE 2018, 13, e0198974. [CrossRef] [PubMed]

86. Fernández-García, J.C.; Muñoz-Garach, A.; Martínez-González, M.Á.; Salas-Salvado, J.; Corella, D.; Hernáez, Á.; Romaguera, D.; Vioque, J.; Alonso-Gómez, Á.M.; Wärnberg, J. Association Between Lifestyle and Hypertriglyceridemic Waist Phenotype in the PREDIMED-Plus Study. Obesity 2020, 28, 537-543. [CrossRef]

87. Corella, D.; Asensio, E.M.; Coltell, O.; Sorlí, J.V.; Estruch, R.; Martínez-González, M.Á.; Salas-Salvadó, J.; Castañer, O.; Arós, F.; Lapetra, J. CLOCK gene variation is associated with incidence of type-2 diabetes and cardiovascular diseases in type-2 diabetic subjects: Dietary modulation in the PREDIMED randomized trial. Cardiovasc. Diabetol. 2016, 15, 1-12. [CrossRef] [PubMed]

88. Ghanim, H.; Aljada, A.; Hofmeyer, D.; Syed, T.; Mohanty, P.; Dandona, P. Circulating mononuclear cells in the obese are in a proinflammatory state. Circulation 2004, 110, 1564-1571. [CrossRef] [PubMed]

89. Toledo, E.; Wang, D.D.; Ruiz-Canela, M.; Clish, C.B.; Razquin, C.; Zheng, Y.; Guasch-Ferré, M.; Hruby, A.; Corella, D.; Gómez-Gracia, E. Plasma lipidomic profiles and cardiovascular events in a randomized intervention trial with the Mediterranean diet. Am. J. Clin. Nutr. 2017, 106, 973-983. [PubMed]

90. Ramawat, K.G.; Mérillon, J.-M. Natural Products: Phytochemistry, Botany and Metabolism of Alkaloids, Phenolics and Terpenes; Springer: Berlin/Heidelberg, Germany, 2013.

91. Finicelli, M.; Squillaro, T.; Di Cristo, F.; Di Salle, A.; Melone, M.A.B.; Galderisi, U.; Peluso, G. Metabolic syndrome, Mediterranean diet, and polyphenols: Evidence and perspectives. J. Cell. Physiol. 2019, 234, 5807-5826. [CrossRef]

92. Baruah, J.B. Chemistry of Phenolic Compounds: State of the Art; Nova Science Publishers: Hauppauge, NY, USA, 2011.

93. Durazzo, A.; Lucarini, M.; Souto, E.B.; Cicala, C.; Caiazzo, E.; Izzo, A.A.; Novellino, E.; Santini, A. Polyphenols: A concise overview on the chemistry, occurrence, and human health. Phyther. Res. 2019, 33, 2221-2243. [CrossRef]

94. El Gharras, H. Polyphenols: Food sources, properties and applications-a review. Int. J. food Sci. Technol. 2009, 44, 2512-2518. [CrossRef]

95. Del Rio, D.; Rodriguez-Mateos, A.; Spencer, J.P.E.; Tognolini, M.; Borges, G.; Crozier, A. Dietary (poly) phenolics in human health: Structures, bioavailability, and evidence of protective effects against chronic diseases. Antioxid. Redox Signal. 2013, 18, 1818-1892. [CrossRef]

96. Kabera, J.N.; Semana, E.; Mussa, A.R.; He, X. Plant secondary metabolites: Biosynthesis, classification, function and pharmacological properties. J. Pharm Pharmacol 2014, 2, 377-392. 
97. Cutrim, C.S.; Cortez, M.A.S. A review on polyphenols: Classification, beneficial effects and their application in dairy products. Int. J. Dairy Technol. 2018, 71, 564-578. [CrossRef]

98. Guasch-Ferré, M.; Merino, J.; Sun, Q.; Fitó, M.; Salas-Salvadó, J. Dietary polyphenols, Mediterranean diet, prediabetes, and type 2 diabetes: A narrative review of the evidence. Oxid. Med. Cell. Longev. 2017, 2017. [CrossRef] [PubMed]

99. Al Shaikh, A.; Braakhuis, A.J.; Bishop, K.S. The mediterranean diet and breast cancer: A personalised approach. Healthcare 2019, 7, 104. [CrossRef]

100. Anderson, J.J.B.; Nieman, D.C. Diet quality-The Greeks had it right! Nutrients 2016, 8, 636. [CrossRef]

101. Ghiselli, A.; Nardini, M.; Baldi, A.; Scaccini, C. Antioxidant activity of different phenolic fractions separated from an Italian red wine. J. Agric. Food Chem. 1998, 46, 361-367. [CrossRef]

102. Godos, J.; Sinatra, D.; Blanco, I.; Mulè, S.; La Verde, M.; Marranzano, M. Association between dietary phenolic acids and hypertension in a mediterranean cohort. Nutrients 2017, 9, 1069. [CrossRef]

103. Kopp, C.; Singh, S.P.; Regenhard, P.; Müller, U.; Sauerwein, H.; Mielenz, M. Trans-cinnamic acid increases adiponectin and the phosphorylation of AMP-activated protein kinase through G-protein-coupled receptor signaling in 3T3-L1 adipocytes. Int. J. Mol. Sci. 2014, 15, 2906-2915. [CrossRef]

104. Alam, M.A.; Subhan, N.; Hossain, H.; Hossain, M.; Reza, H.M.; Rahman, M.M.; Ullah, M.O. Hydroxycinnamic acid derivatives: A potential class of natural compounds for the management of lipid metabolism and obesity. Nutr. Metab. 2016, 13, 27. [CrossRef]

105. Luna-Vital, D.; Luzardo-Ocampo, I.; Cuellar-Nuñez, M.L.; Loarca-Piña, G.; de Mejia, E.G. Maize extract rich in ferulic acid and anthocyanins prevents high-fat-induced obesity in mice by modulating SIRT1, AMPK and IL-6 associated metabolic and inflammatory pathways. J. Nutr. Biochem. 2020, 79, 108343. [CrossRef] [PubMed]

106. Panche, A.N.; Diwan, A.D.; Chandra, S.R. Flavonoids: An overview. J. Nutr. Sci. 2016, 5, e47. [CrossRef]

107. Román, G.C.; Jackson, R.E.; Gadhia, R.; Román, A.N.; Reis, J. Mediterranean diet: The role of long-chain $\omega-3$ fatty acids in fish polyphenols in fruits, vegetables, cereals, coffee, tea, cacao and wine; probiotics and vitamins in prevention of stroke, age-related cognitive decline, and Alzheimer disease. Rev. Neurol. 2019, 175, 724-741. [CrossRef] [PubMed]

108. Chuang, C.-C.; Shen, W.; Chen, H.; Xie, G.; Jia, W.; Chung, S.; McIntosh, M.K. Differential effects of grape powder and its extract on glucose tolerance and chronic inflammation in high-fat-fed obese mice. J. Agric. Food Chem. 2012, 60, 12458-12468. [CrossRef] [PubMed]

109. Martino, H.S.D.; dos Santos Dias, M.M.; Noratto, G.; Talcott, S.; Mertens-Talcott, S.U. Anti-lipidaemic and anti-inflammatory effect of açai (Euterpe oleracea Martius) polyphenols on 3T3-L1 adipocytes. J. Funct. Foods 2016, 23, 432-443. [CrossRef]

110. Kawser Hossain, M.; Abdal Dayem, A.; Han, J.; Yin, Y.; Kim, K.; Kumar Saha, S.; Yang, G.-M.; Choi, H.Y.; Cho, S.-G. Molecular mechanisms of the anti-obesity and anti-diabetic properties of flavonoids. Int. J. Mol. Sci. 2016, 17, 569. [CrossRef] [PubMed]

111. Song, D.; Cheng, L.; Zhang, X.; Wu, Z.; Zheng, X. The modulatory effect and the mechanism of flavonoids on obesity. J. Food Biochem. 2019, 43, e12954. [CrossRef] [PubMed]

112. Serreli, G.; Deiana, M. Biological Relevance of Extra Virgin Olive Oil Polyphenols Metabolites. Antioxidants 2018, 7, 170. [CrossRef]

113. Visioli, F.; Bellomo, G.; Montedoro, G.; Galli, C. Low density lipoprotein oxidation is inhibited in vitro by olive oil constituents. Atherosclerosis 1995, 117, 25-32. [CrossRef]

114. Bulotta, S.; Celano, M.; Lepore, S.M.; Montalcini, T.; Pujia, A.; Russo, D. Beneficial effects of the olive oil phenolic components oleuropein and hydroxytyrosol: Focus on protection against cardiovascular and metabolic diseases. J. Transl. Med. 2014, 12, 219. [CrossRef]

115. Cao, K.; Xu, J.; Zou, X.; Li, Y.; Chen, C.; Zheng, A.; Li, H.; Li, H.; Szeto, I.M.-Y.; Shi, Y.; et al. Hydroxytyrosol prevents diet-induced metabolic syndrome and attenuates mitochondrial abnormalities in obese mice. Free Radic. Biol. Med. 2014, 67, 396-407. [CrossRef]

116. Novotny, J.A.; Chen, T.; Terekhov, A.I.; Gebauer, S.K.; Baer, D.J.; Ho, L.; Pasinetti, G.M.; Ferruzzi, M.G. The effect of obesity and repeated exposure on pharmacokinetic response to grape polyphenols in humans. Mol. Nutr. Food Res. 2017, 61, 1700043. [CrossRef]

117. Park, D.-W.; Baek, K.; Kim, J.-R.; Lee, J.-J.; Ryu, S.-H.; Chin, B.-R.; Baek, S.-H. Resveratrol inhibits foam cell formation via NADPH oxidase 1-mediated reactive oxygen species and monocyte chemotactic protein-1. Exp. Mol. Med. 2009, 41, 171-179. [CrossRef]

118. Sebai, H.; Sani, M.; Yacoubi, M.T.; Aouani, E.; Ghanem-Boughanmi, N.; Ben-Attia, M. Resveratrol, a red wine polyphenol, attenuates lipopolysaccharide-induced oxidative stress in rat liver. Ecotoxicol. Environ. Saf. 2010, 73, 1078-1083. [CrossRef]

119. De Groote, D.; Van Belleghem, K.; Devière, J.; Van Brussel, W.; Mukaneza, A.; Amininejad, L. Effect of the intake of resveratrol, resveratrol phosphate, and catechin-rich grape seed extract on markers of oxidative stress and gene expression in adult obese subjects. Ann. Nutr. Metab. 2012, 61, 15-24. [CrossRef]

120. Khaldi, D.; Belarbi, M.; El Haci, I.A.; Atik, F.; Zeriouh, W.; Ghanemi, F.Z.; Nani, A.; Hichami, A. Antioxidant Activity and Determination of Gallic Acid and Quercetin in Osyris alba L. Root Extract. The Root Oil Contains Essential Fatty Acids. Phytothérapie 2018, 16, S84-S95. [CrossRef]

121. Hameed, S.; Imran, A.; Nisa, M.U.; Arshad, M.S.; Saeed, F.; Arshad, M.U.; Asif Khan, M. Characterization of extracted phenolics from black cumin (Nigella sativa linn), coriander seed (Coriandrum sativum L.), and fenugreek seed (Trigonella foenum-graecum). Int. J. Food Prop. 2019, 22, 714-726. [CrossRef]

122. Vasilopoulou, E.; Georga, K.; Joergensen, M.B.; Naska, A.; Trichopoulou, A. The antioxidant properties of Greek foods and the flavonoid content of the Mediterranean menu. Curr. Med. Chem. Endocr. Metab. Agents 2005, 5, 33-45. [CrossRef] 
123. Gorinstein, S.; Leontowicz, H.; Leontowicz, M.; Namiesnik, J.; Najman, K.; Drzewiecki, J.; Cvikrová, M.; Martincová, O.; Katrich, E.; Trakhtenberg, S. Comparison of the Main Bioactive Compounds and Antioxidant Activities in Garlic and White and Red Onions after Treatment Protocols. J. Agric. Food Chem. 2008, 56, 4418-4426. [CrossRef] [PubMed]

124. Irakli, M.N.; Samanidou, V.F.; Biliaderis, C.G.; Papadoyannis, I.N. Development and validation of an HPLC-method for determination of free and bound phenolic acids in cereals after solid-phase extraction. Food Chem. 2012, 134, 1624-1632. [CrossRef]

125. Ramírez-Garza, S.L.; Laveriano-Santos, E.P.; Marhuenda-Muñoz, M.; Storniolo, C.E.; Tresserra-Rimbau, A.; Vallverdú-Queralt, A.; Lamuela-Raventós, R.M. Health effects of resveratrol: Results from human intervention trials. Nutrients 2018, 10, 1892. [CrossRef]

126. Brenes, M.; García, A.; Dobarganes, M.C.; Velasco, J.; Romero, C. Influence of thermal treatments simulating cooking processes on the polyphenol content in virgin olive oil. J. Agric. Food Chem. 2002, 50, 5962-5967. [CrossRef] [PubMed]

127. Camps, J. Oxidative Stress and Inflammation in Non-communicable Diseases-Molecular Mechanisms and Perspectives in Therapeutics; Springer: Berlin/Heidelberg, Germany, 2014.

128. Santilli, F.; Guagnano, M.T.; Vazzana, N.; La Barba, S.; Davi, G. Oxidative stress drivers and modulators in obesity and cardiovascular disease: From biomarkers to therapeutic approach. Curr. Med. Chem. 2015, 22, 582-595. [CrossRef] [PubMed]

129. Carpi, S.; Scoditti, E.; Massaro, M.; Polini, B.; Manera, C.; Digiacomo, M.; Esposito Salsano, J.; Poli, G.; Tuccinardi, T.; Doccini, S. The Extra-Virgin Olive Oil Polyphenols Oleocanthal and Oleacein Counteract Inflammation-Related Gene and miRNA Expression in Adipocytes by Attenuating NF-kB Activation. Nutrients 2019, 11, 2855. [CrossRef]

130. Kwaifa, I.K.; Bahari, H.; Yong, Y.K.; Noor, S.M. Endothelial Dysfunction in Obesity-Induced Inflammation: Molecular Mechanisms and Clinical Implications. Biomolecules 2020, 10, 291. [CrossRef] [PubMed]

131. Zuo, X.; Tian, C.; Zhao, N.; Ren, W.; Meng, Y.; Jin, X.; Zhang, Y.; Ding, S.; Ying, C.; Ye, X. Tea polyphenols alleviate high fat and high glucose-induced endothelial hyperpermeability by attenuating ROS production via NADPH oxidase pathway. BMC Res. Notes 2014, 7, 120. [CrossRef]

132. Martinez, J.; Moreno, J.J. Effect of resveratrol, a natural polyphenolic compound, on reactive oxygen species and prostaglandin production. Biochem. Pharmacol. 2000, 59, 865-870. [CrossRef]

133. Chuang, C.-C.; McIntosh, M.K. Potential mechanisms by which polyphenol-rich grapes prevent obesity-mediated inflammation and metabolic diseases. Annu. Rev. Nutr. 2011, 31, 155-176. [CrossRef]

134. De Marchi, E.; Baldassari, F.; Bononi, A.; Wieckowski, M.R.; Pinton, P. Oxidative stress in cardiovascular diseases and obesity: Role of p66Shc and protein kinase C. Oxid. Med. Cell. Longev. 2013, 2013. [CrossRef] [PubMed]

135. Yang, J.; Han, Y.; Chen, C.; Sun, H.; He, D.; Guo, J.; Jiang, B.; Zhou, L.; Zeng, C. EGCG attenuates high glucose-induced endothelial cell inflammation by suppression of PKC and NF- $\mathrm{BB}$ signaling in human umbilical vein endothelial cells. Life Sci. 2013, 92, 589-597. [CrossRef]

136. Rechner, A.R.; Wagner, E.; Van Buren, L.; Van De Put, F.; Wiseman, S.; Rice-Evans, C.A. Black tea represents a major source of dietary phenolics among regular tea drinkers. Free Radic. Res. 2002, 36, 1127-1135. [CrossRef]

137. Boyer, J.; Brown, D.; Liu, R.H. Uptake of quercetin and quercetin 3-glucoside from whole onion and apple peel extracts by Caco-2 cell monolayers. J. Agric. Food Chem. 2004, 52, 7172-7179. [CrossRef]

138. Yen, G.-C.; Chen, Y.-C.; Chang, W.-T.; Hsu, C.-L. Effects of polyphenolic compounds on tumor necrosis factor- $\alpha$ (TNF- $\alpha)$-induced changes of adipokines and oxidative stress in 3T3-L1 adipocytes. J. Agric. Food Chem. 2011, 59, 546-551. [CrossRef] [PubMed]

139. Chartoumpekis, D.V.; W Kensler, T. New player on an old field; the keap1/Nrf2 pathway as a target for treatment of type 2 diabetes and metabolic syndrome. Curr. Diabetes Rev. 2013, 9, 137-145. [CrossRef] [PubMed]

140. Boesch-Saadatmandi, C.; Loboda, A.; Wagner, A.E.; Stachurska, A.; Jozkowicz, A.; Dulak, J.; Döring, F.; Wolffram, S.; Rimbach, G. Effect of quercetin and its metabolites isorhamnetin and quercetin-3-glucuronide on inflammatory gene expression: Role of miR-155. J. Nutr. Biochem. 2011, 22, 293-299. [CrossRef]

141. Snyder, S.M.; Zhao, B.; Luo, T.; Kaiser, C.; Cavender, G.; Hamilton-Reeves, J.; Sullivan, D.K.; Shay, N.F. Consumption of quercetin and quercetin-containing apple and cherry extracts affects blood glucose concentration, hepatic metabolism, and gene expression patterns in obese C57BL/6J high fat-fed mice. J. Nutr. 2016, 146, 1001-1007. [CrossRef] [PubMed]

142. Chen, C.-Y.; Peng, W.-H.; Tsai, K.-D.; Hsu, S.-L. Luteolin suppresses inflammation-associated gene expression by blocking NF-kB and AP-1 activation pathway in mouse alveolar macrophages. Life Sci. 2007, 81, 1602-1614. [CrossRef]

143. Galic, S.; Fullerton, M.D.; Schertzer, J.D.; Sikkema, S.; Marcinko, K.; Walkley, C.R.; Izon, D.; Honeyman, J.; Chen, Z.-P.; van Denderen, B.J. Hematopoietic AMPK $\beta 1$ reduces mouse adipose tissue macrophage inflammation and insulin resistance in obesity. J. Clin. Investig. 2011, 121, 4903-4915. [CrossRef] [PubMed]

144. Gauthier, M.-S.; O’Brien, E.L.; Bigornia, S.; Mott, M.; Cacicedo, J.M.; Xu, X.J.; Gokce, N.; Apovian, C.; Ruderman, N. Decreased AMP-activated protein kinase activity is associated with increased inflammation in visceral adipose tissue and with whole-body insulin resistance in morbidly obese humans. Biochem. Biophys. Res. Commun. 2011, 404, 382-387. [CrossRef]

145. Huang, Y.; Zhu, X.; Chen, K.; Lang, H.; Zhang, Y.; Hou, P.; Ran, L.; Zhou, M.; Zheng, J.; Yi, L. Resveratrol prevents sarcopenic obesity by reversing mitochondrial dysfunction and oxidative stress via the PKA/LKB1/AMPK pathway. Aging 2019, 11, 2217. [CrossRef]

146. Gonzales, A.M.; Orlando, R.A. Curcumin and resveratrol inhibit nuclear factor-kappaB-mediated cytokine expression in adipocytes. Nutr. Metab. 2008, 5, 17. [CrossRef] 